\title{
BACTERIOLOGICAL ASSESSMENT OF RAW MILK AND YOGHURT FOR PRESENCE OF STAPHYLOCOCCUS AUREUS WITH SPECIAL REFERENCE TO ITS ENTEROTOXINS
}

\author{
M.F. HUSSIEN ${ }^{1}$ and A.M. KOREIM ${ }^{2}$ \\ ${ }^{1}$ Food Hygiene Department, Animal Health Research Institute, Assiut Lab. \\ ${ }^{2}$ Bacteriology Department, Animal Health Research Institute, Assiut Lab.
}

Received: 13 December 2015; Accepted: 10 January 2016

\begin{abstract}
A total of 150 of raw milk and yoghurt samples (75 of each) were obtained from different small daries and supermarkets in Assiut city, Egypt and were examind for presence of Staph aureus. The isolated strains were examined for the production of Staphylococcal enterotoxins (SEs) using the enzyme - linked immunosorbant assay (ELISA) method. 39(52\%) out of 75 examind raw milk samples were positive for Staph aureus while the organism failed to detect in yoghurt. Out of 39 Staph aureus isolates $12(30.8 \%)$ were positive for at least 1SE, out of which 5(41.7\%) were positive for SEA 3(25\%) for SEC, 2(16.7\%) for SED. Two isolates of Staph aureus are able to produce more than one type of enterotoxin as one strain produce SEA\&C and another produce C\&D, both in percentage of $8.3 \%$. It could concluded that examind milk samples were contaminated with enterotoxigenic strains of Staph. aureus and the public health hazards of SEs were also discussed.
\end{abstract}

Key words: Bacteriological Assessment, Raw Milk, Yoghurt, Staphylococcus Aureus.

\section{INTRODUCTION}

Milk has long been referred to as the most perfect food for human consumption from birth to senility; it contains all the nutrients required for rapid growth and healthy development of the body. Milk and its products have been shown to be an ideal media for growth and multiplication of many microorganisms; including Staphylococcal food poisoning (Bone et al., 1989 and Wieneke et al., 1993). Staphylococcus aureus contamination can occur through its presence in raw milk itself or during its processing (Le Loir et al., 2003).

Yoghurt is the most popular type of fermented milk in Egypt, the nutritive value of yoghurt is attributed to the fat content, sugar and casein. Therefore, yoghurt is recommended for sick and convalescent people. It inhibits the bacterial flora of intestine which may lead to constipation, autointoxication and colitis as well as it helps in the absorbtion of calcium and phosphorous.

Staphylococcus aureus infection was estimated to be present in up to $90 \%$ of dairy farms and is responsible for $35 \%$ of the economic loss in the dairy industry (Bone et al., 1989). Moreover Staphylococcus aureus is facultative anaerobic Gram positive bacterium, the majority of Staph. aureus strains are catalse and coagulase positive which forms the basis of traditional identification methodology.

Corresponding author: Dr. M.F. HUSSIEN

E-mail address: Mahmoutfarghaly_1970@yahoo.com

Present address: Food Hygiene Department, Animal Health Research Institute, Assiut Lab.
Staphylococcus aureus is a leading cause of food poisoning resulting from the consumption of contaminated food with staphylococcal enterotoxins. Exactly, Staph. aureus is considered the world's third most important cause of food-born illnesses due to its ability to graw and produce enterotoxins (SEs) under a wide range of conditions.

The pathogenicity of Staph. aureus and its ability to cause diseases is attributed to a number of virulence factors such as the heat stable enterotoxins (Sande and Mckilli, 2004). Staph. aureus produces 15 enteotoxins (Atichou et al., 2004). The five classical enterotoxins (SEs type A, B, C, D and E) were known to be responsible for $95 \%$ of Staphylococcal food poisoning (SFP) cases, the rest of cases were due to the new types of SEs (SE G - SE O) (Wang et al., 2012). However, the role of newly identified enterotoxins in food poisoning is not fully clarified, and the development of methods for the detection of these novel SE genes is of critical importance for food poisoning investigations.

The staphylococcal food poisning (SEP) is a mild intoxication occurring after the ingestion of food containing from $20 \mathrm{ng}$ up to1 ug of Staphylococal enterotoxins (SEs) which is enough to induce symptoms in human beings (Nermano et al., 2007). The SFP symptoms appear 1-6 h after ingestion of contaminated food, depending on individual and toxic dose ingested. They include nauseas, abdominal cramps, diarrhea, general malaise, weakness and characteristic projectile vomiting. Clinical signs of SFP generally disappear within 24-48 h. Deaths occur 
rarely and specifically in the very young or elderly (Jay et al., 2005).

Enterotoxins are highly thermostable, normal cooking and pasteurization cannot totally inactivate them leading to food poisoning (Nagarajappa et al., 2012). Pasteurization kills Staph. aureus cells, and fermentation or ripening of cheese may prevent growth of Staph. aureus in raw milk cheese. However, once formed the thermostable SEs generally retain their biological activity (Le Loir et al., 2003 and Becker et al., 2007). Although SEs a generally heat resistant and a heat denatured enterotoxin, it can be renatured by prolonged storage or in the presence of urea. The SEs also are resist most proteolytic enzymes such as pepsin or trypsin thus keep their activity in the digestive tract after ingestion and are capable of causing food poisoning (Lee Loir et al., 2003).

Because of the importance of these toxins in the public health and food sectors, an efficient screening methods to detect the prevalence of Staphylococcal enterotoxins (SEs) in food are required. The present work was planned to investigate the prevalence of Staph. aureus in raw milk and yoghurt samples and identification of enterotoxigenic Staph. aureus isolates using ELISA technique.

\section{MATERIALS AND METHODS}

A total of 150 random raw milk and yoghurt samples (75 of each) were collected from small dairies and supermarkets in Assiut city, Egypt. The samples were collected in clean, sterile plastic bags as marketed to the consumers. The samples were transferred in an ice box as rapidly as possible to the laboratory were subjected to microbilogical examination:-

I- Isolation of Staphylococcus aureus: according to (FDA, 2001).

A- Isolation.

Samples were inoculated on Baird-Parker agar plates and incubated at $35{ }^{0} \mathrm{C}$ for $48 \mathrm{~h}$. The typical appearance of Staph. aureus colonies are circular, smooth, convex, moist, $2-3 \mathrm{~mm}$ in diameter, gray to jet-black, frequently with light-colored (off-white) margin, surrounded by opaque zone and frequently with an outer clear zone. Inoculated typical colonies on TSA slants were used for maintenance and further identification.

B- Identification.

1- Microscopical appearance.

2- Catalase test.

Growth from TSA slant was used for catalase test on glass slide or spot plate, and illuminated properly to observe production of gas bubbles.

\section{3- Coagulase test.}

Suspected Staph. aureus colonies were inoculated into small tubes containing 0.2-0.3 ml BHI broth and emulsified thoroughly and incubated at $35{ }^{0} \mathrm{C}$ for 18 $24 \mathrm{~h}$ then $0.5 \mathrm{ml}$ of reconstituted coagulase plasma with EDTA was added to the BHI culture and mixed thoroughly. The tube was incubated at $35^{\circ} \mathrm{C}$ and examined periodically over $6 \mathrm{~h}$ period for clot formation.

\section{4- Anaerobic utilization of glucose}

Tube of carbohydrate fermentation medium containing glucose $(0.5 \%)$ was inoculated with suspected organism. The tube surface covered with sterile paraffin oil at least $25 \mathrm{~mm}$ thick and incubated for 5 days at $37^{\circ} \mathrm{C}$. Acid is produced anaerobically if indicator changes to yellow throughout tube, indicating presence of $S$. aureus.

5- Lysostaphin sensitivity.

Isolated colony transferred from agar plate with inoculating loop to $0.2 \mathrm{ml}$ phosphate-saline buffer, and emulsified. Half of suspended cells was transferred to another tube $(13 \times 100 \mathrm{~mm})$ and mixed with $0.1 \mathrm{ml}$ phosphate saline buffer as control. Add $0.1 \mathrm{ml}$ lysostaphin (dissolved in $0.02 \mathrm{M}$ phosphatesaline buffer containing $1 \% \mathrm{NaCl}$ ) to original tube for concentration of $25 \mu \mathrm{g}$ lysostaphin $/ \mathrm{ml}$. Both tubes were incubated at $35^{\circ} \mathrm{C}$ for not more than $2 \mathrm{~h}$. If turbidity clears in test mixture, test is considered positive. If clearing has not occurred in $2 \mathrm{~h}$, test is negative. Staph. aureus is generally positive.

II- Determination of Staphylococcus aureus enterotoxins: Staph. aureus isolates (39 strains) from raw milk samples were performed in Food Analysis Center, Faculty of Veterinary Medicine, Benha Univirsity, Egypt, by using ELISA technique according to (Ewald, 1988) as following:-

Accurately, RIDASCREEN set C (Art No.: R4101, R-Biopharm AG, Darmstadt, Germany) is an enzyme immunoassay for the determination of Staph. aureus enterotoxins by using their definite kits.

According to the test kit manual, a loopful of the culture was mixed in sterile buffer saline and then shaken for 15 minutes. After centrifugation for 10 minutes at 3500 r.p.m, sterile filtration of the supernatant was applied. An aliquot $(100 \mu \mathrm{l}$ per kit well) of this solution was used in the test. Further, the last well was represented as positive control. They were mixed gently and incubated for one hour at room temperature $\left(20-25^{\circ} \mathrm{C}\right)$ in the dark.

The liquid was dumped out of the wells into a sink to remove all of the remaining liquid from the wells. Therefore, the wells were then filled with $250 \mu \mathrm{l}$ of washing buffer and the liquid was poured out again. The washing step was repeated 3 more times to remove the unbound conjugate. 
Subsequently, $100 \mu \mathrm{l}$ of enzyme conjugate were added to each well and incubated for one hour at room temperature in the dark after mixing gently. The liquid was dumped out of the wells into a sink and the wells were each filled with $250 \mu$ of the washing buffer. The liquid was poured out again and the wells were emptied to remove all of the remaining liquid. The washing step was repeated 3 more times again.

Afterwards, $50 \mu \mathrm{l}$ of substrate and $250 \mu \mathrm{l}$ of chromogen solutions were added to each well. The solutions were mixed gently and incubated for 30 minutes at room temperature in the dark. Finally, 100 $\mu \mathrm{l}$ of the stop solution (1M H2 SO4) were added to each well with gentler mixing.

By using ELISA, the absorbance was measured at $450 \mathrm{~nm}$ in an ELISA plate reader (ELX800, BioTek Instruments, Bad Friedrichshall, Germany). The results were calculated from standard curve.

\section{RESULTS}

Table 1: Incidence of Staphylococcus aureus in the examined raw milk and yoghurt samples.

\begin{tabular}{cccccc}
\hline \multirow{2}{*}{ Type of samples } & No. of samples & \multicolumn{2}{c}{ Positive } & \multicolumn{2}{c}{ Negative } \\
\cline { 2 - 6 } & 75 & No. & $\%$ & No. & $\%$ \\
\hline Raw milk & 75 & 39 & 52 & 36 & 48 \\
\hline Yoghurt & 0 & 0 & 75 & 100 \\
\hline
\end{tabular}

Table 2: The distribution of Staphylococcus aureus enterotoxins recovered from raw milk samples.

\begin{tabular}{|c|c|c|c|c|c|c|c|c|c|c|c|c|}
\hline \multirow{2}{*}{$\begin{array}{l}\text { No. of tested } \\
\text { isolates }\end{array}$} & \multicolumn{2}{|c|}{$\begin{array}{c}\text { Positive } \\
\text { isolates for } \\
\text { SEs }\end{array}$} & \multicolumn{10}{|c|}{ Types and frequency of enterotoxins } \\
\hline & No. & $\%$ & A & $\%$ & $\mathrm{C}$ & $\%$ & $\mathrm{D}$ & $\%$ & $A \& C$ & $\%$ & $C \& D$ & $\%$ \\
\hline 39 & 12 & 30.8 & 5 & 41.7 & 3 & 25 & 2 & 16.7 & 1 & 8.3 & 1 & 8.3 \\
\hline
\end{tabular}

\section{DISCUSSION}

The results illusterated in Table (1) revealed that, $52 \%$ of the examined raw milk samples were contaminated with Staphylococcus aureus. Nearly similar results 52 and 56.66 were reported by Pourhassan and Taravat, (2011) and EL-Jakee et al. (2013), respectively. However, higher results were recorded by Al-Tarazi et al. (2003); Ekici et al. (2004) and Oliveira et al. (2011) in percentages of 80, 75 and $58 \%$, respectively. While, lower results were estimated by Yagoub et al. (2005); Singh et al. (2011); Khuder et al. (2012); Meshref (2013); Thaker et al. (2013) and Vahedi et al. (2013).

Presence of Staphylococus aureus in raw milk cold be attributed to many causes such as subclinical mastitis, where Staph. aureus was the most isolated bacteria or due to contamination of raw milk by milkers and milk handlers. Also, inadequate refrigeration and long storage of milk before use help growth of Staph. aureus (Asperger, 1994). In addition, negligence of hygienic condition such as improper cleaning of bulk tank, dirty udder, milk equipments, milk handling techniques and improper storage will increase the proportion of Gram-positive and Gram-negative bacteria in the bulk tank milk (Bonfoh et al., 2003).

Concerning examined yoghurt samples, Staph. aureus couldn't be detected in the present study. Similar results were obtained by Rodriguez et al. (1990); ElBessery (2001) and Isam et al. (2011). The failure of Staph. aureus detection in this study may be due to $\mathrm{pH}$ of yoghurt, lactic acid and inhibitory substances produced by yoghurt culture which reduce or inhibit Staph. aureus growth in yoghurt (Pazakova et al., 1997). Moreover, such organisms was inhibited after few days during storage of fermented products (Estrada et al., 1999).

Table (2) illusterated the distribution of Staph. aureus enterotoxins recovered from raw milk samples by using ELISA technique, where the ability to 
synthesize enterotoxins was found in $12(30.8 \%)$ out of 39 isolates of Staph. aureus.

Five isolate $(41.7 \%)$ produce SEA, three isolate $(25 \%)$ produce SEC, two isolates $(16.7 \%)$ produce SED, one isolate produce SE A\&C and another isolate produce $\mathrm{SE} C \& \mathrm{D}$, both in percentage of $8.3 \%$.

Of the twelve Enterotoxigenic positive isolates of Staph. aureus, two isolates only are able to produce more than one enterotoxins (one produce A \& $\mathrm{C}$ and another produce $\mathrm{C} \& \mathrm{D}$ ), while, all the remaining 10 isolates were able to produce one enterotoxin only.

These findings were nearly similar to that detected by Nermano et al. (2007) and Rahimi et al. (2012) who detected similar findings of enterotoxin A. However, some of the present finding differ from those reported by other researchers in other countries, such studies have indicated that SEC was the most predominant type (Stephen et al., 2001; Jorgensen et al., 2001; Katsuda et al., 2005 and Loncarevic et al., 2005).

Staphylococcal enterotoxins SEA and SEB are the most important gastroenteritis causing agents. In some areas, more than $50 \%$ of food poisoning is caused by SEA and SEB (> 60\%) in USA and England (Kluytman and Werthein 2005). SEA is the most common enterotoxin recovered from foodpoisoning outbreak in US $(77.8 \%)$ followed by SED $(37.5 \%)$ and SEB (10\%) (Rall et al., 2008).

In conclusion Staph. aureus producing enterotoxins could be isolated from examind raw milk samples, so most official regulations should stricktly require the absence of Staph. aureus and its enterotoxins in milk and dairy products which could be highlighted Using ELISA technique.

\section{REFERENCES}

Al-Tarazi, Y.; Al-Zamil, A.; Shaltout, F. and AbdelSamei, H. (2003): Sanitary status of raw cow milk marketed in northern Jordan. Assiut Vet. Med. J., 49 (96): 180-194.

Asperger, H. (1994): The significance of pathogenic microorganisms in raw milk. International Dairy Federation (IDF). Document No. 292. Belgium.

Atichou, M.; Henkens, R.; Sultana, A.; Ulrich, R. and Ibrahim, M. (2004): Detection of Staphylococcus aureus enterotoxin A and B genes with PCR-ELISA and hand-hand electrochemical sensor. Mo. Cell Probes, 18: 373-377.

Becker, H.; Bûrk, C. and Mârtlbaure (2007): Staphylokokhen-Enterotoxin: Bildung. Eigen Schaften und Nachweis. J. Verbr Lebensm, 2: 171-189.
Bone, F.J.; Bogie, D. and Morgan, S.C. (1989): Staphylococcal food poisoning from sheep mil cheese. Epidemiology Infect., 103: 449-458.

Bonfoh, B.; Wasem, A.; Traore, A.; Fane, A.; Spillmann, H.; Simbe, C.; Alfaroukh, I.; Nicolet, J.; Farah, Z. and Zinsstag, J. (2003): Microbiological quality of cow's milk taken at different intervals from the udder to the selling point in Bamako (Mali). Food Control, 14: 495-500.

Ekici, K.; Bozkurt, H. and Isleyici, O. (2004): Isolation of some pathogens from raw milk of different milch animals. Pakistan J. Nutrition, 3 (3): 161-162.

El-Bessery, M.M. (2001): Microbiological quality of market fermented milks in Assiut city. M.V.Sc. Thesis, Fac. Vet. Med., Assiut Univ., Egypt.

El-Jakee, j; Marouf, S.A.; Ata, Nagwa,; Eman H.; Abdel-Rahmam, Sherein, I.; Abd-El-Moez; Samy, A.A. and EL-Sayed, Walaa, E. (2013): Method for detecting of Staphylococcus aureus Enterotoxins in Food. Global Veterinaria, 11(3): 335-341.

Estrada, Z.A.; Mendoza, S.M.; La Garza, M.L. and Ferado, J. (1999): Behavior of enterotoxigenic strains of Staphylococcus aureus in milk fermented with yoghurt starter culture. Rev. Latinoam Microbiol., 41 (1): 5-10.

Ewald, S. (1988): Evaluation of enzyme-linked immunosorbant assay (ELISA) for detection of staphylococcal enterotoxins in foods. Int. J. Food. Microbiol., 6 (2): 141-153.

F.D.A. (2001): Food and Drug Administration (Bacteriological Analytical Manual). Staphylococcus aureus. Chapter: 12, January 2001.http://www.fda.gov/Food/ScienceResearc h/ LaboratoryMethods/ Bacteriological AnalyticalManualBAM/UCM071429.

Isam, A.M.; Eshraga, A.E.; Abu-Elgasim, A.Y and Efadil, E.B. (2011): Physicochemical, microbiological and sensory characteristics of yoghurt produced from camel milk during storage. Electronic J. Envi. Agricult. Food Chemistry, 10 (6): 2305-2313.

Jay, M.J.; Loessner, J.M; and Golden, A.D. (2005): Staphylococcal gastroenteritis. In: Modern Food Microbiology. $7^{\text {th }}$ edition. Springer

Jorgensen, H.J.; Mark, T.; Hogasen, H.R. and Rovik, L.M. (2001): Implication of milk and milk products in food-borne diseases in France and in different industrized countries. Int. J. Food Microbiol., 67: 1-17.

Katsuda, K.; Hatab, E.; Kobayshi, H.; Kohmoto, M.; Kawshima, K.; Tsunemitsu, H. and Eguchi, M. (2005): Moleculer typing of Staphylococcus aureus isolated from bovine mastitic milk on the basis of toxigenes and coagulase genes polymorphisms. Vet. Microbiol., 105: 301-305.

Khuder, M.H.; Abbas, B.A. and Idbeis, H.I. (2012): Detection of enterotoxin genes of 
Staphylococcus aureus isolates from raw milk. Basrah J. Vet. Res., 11 (1):254-264.

Kluytman, J.A.J.W. and Werthein, H.F.L. (2005): Nasal carriage of Staphylococus aureus and prevention of nosocomial infections. Infection, 33: 3-7.

Le Loir, Y.; Baron, F. and Gautier, M. (2003): Staphylococcus aureus and food poisoning. Genet. Mol. Res., 2: 63-76.

Loncarevic, S.; Jorgensen, H.; Lovseth, A.; Mathiser, T. and Rorvik, L.M. (2005): Diversity of Staphylococcus aureus enterotoxin types within single samples of raw milk and raw milk products. J. Appl. Microbiol., 98: 344-350.

Meshref, A.M.S. (2013): Bacteriological quality and safety of raw cow's milk and fresh cream. Slov. Vet. Res., 50 (1): 21-30.

Microbiological quality of cow's milk taken at different intervals from the udder to the selling point in Bamako (Mali). Food Control, 14: 495-500.

Nagarajappa, S.; Thakur, M.S. and Manonmani, H.K. (2012): Detection of enterotoxigenic Staphylococci by Loop-mediated isothermal amplification method. J. Food Safety, 32: 5965.

Nermano, T.G.; La Salandra, G.; Dambrosia, A.; Quaglia, N.C.; Corrent, M.; Paris, A.; Santagada, G.; Firina, A.; Crisetti, E. and Celano, G.V. (2007): Occurrence, characterization and antimicrobial resistance of enterotoxigenic Staphylococcus aureus strains isolated from meat and dairy products. Int. J. Food. Microbiol., 115: 290-296.

Oliveira, Lílian, P.; Barros, Ludmilla, S.; Silva, V.C. and Cirqueira, Marina, C. (2011): Study of Staphylococcus aureus in raw and pasteurized milk consumed in the Reconcavo area of the State of Bahia, Brazil. J Food Process Technol., 2 (6): 1-6.

Pazakova, J.; Turek, P. and Laciakova, A. (1997): The survival of Staphylococcus aureus during the fermentation and storage of yoghurt. J. Appl. Microbiol., 82: 659-662.

Pourhassan, M. and Taravat, N. (2011): The Spatial Distribution of Bacteria Pathogens in Raw Milk Consumption on Malayer City, Iran. Shiraz E-Medical J., 12 (1): 1-9. Available at http://semj.sums.ac.ir/vol12/jan2011/88047.ht m.

Rahimi, E.; Mommtaz, H.; Shakerian, A. and Kavyani, H. (2012): The detection of classical enterotoxins of Staphylococcus aureus in raw cow milk using the ELISA method. Turk. J. Vet. Anim. Sci., 36 (3): 319-322.

Rall, V.L.; Vieira, F.P.; Rall, R.; Vieitis, R.L.; Fernandes, A.J.R.; Candeias, J.M.; Cardoso, K.F. and Araujo, J.P.J. (2008): PCR detection of Staphylococcal enterotoxin genes in Staphylococcus aureus strains isolated from raw and pasteurized milk. Vet. Microbiol., 10: 408-413.

Rodriguez, A.C.; Pintor, D.M.; Gonzalez, P.A.; Alvarez, M.R. and Hardisson, D.A. (1990): Microorganisms of Food hygiene interest in commercial yoghurts in the Canary islands. Alimentaria, 212: 55-58.

Sande, M. and Mckilli, P. (2004): Virulence and recovery of Staphylococcus aureus relevant to food using improvement traditional approaches. Food Control, 15: 5-10.

Singh, V.; Kaushal, S.; Tyagi, A. and Sharma, P. (2011): Screening of bacteria responsible for the spoilage of milk. J. Chem. Pharm. Res., 3(4): 348-350.

Stephen, R.; Annemuuler, C.; Hassan, A.A. and Lammler, C.H. (2001): Characterization of enterotoxogenic Staphylococcus aureus stains isolated from bovine mastitis in north-east Switzerland. Vet. Microbiol., 78: 373-382.

Thaker, H.C.; Brahmbhatt, M.N. and Nayak, J.B. (2013): Isolation and identification of Staphylococcus aureus from milk and milk products and their drug resistance patterns in Anand, Gujarat. Vet. World, 6 (1):10-13.

Vahedi, M.; Nasrolahei, M.; Sharif, M. and Mirabi, A. (2013): Bacteriological study of raw and unexpired pasteurized cow's milk collected at the dairy farms and super markets in Sari City in 2011. J. Prev. Med. Hyg., 54: 120-123.

Wang, X.; Meng, J.; Zhang, T.; Zhang, Y.; Zhang, B. and Xia, X. (2012): Characterization of Staphylococcus aureus isolated from powdered infant formula milk and infant rice cereal in China. Int. J. Food Microbiol., 153 (1-2): 142147.

Wieneke, A.A.; Roberts, D. and Gilbert, R.J. (1993): Staphylococal food poisoning in United Kingdom. 1969 - 90. Epidemilogy Infect., 110: 519-531.

Yagoub Sanaa, O.; Awadalla Nazik, E. and El Zubeir Ibtisam, E.M. (2005): Incidence of some potential pathogens in raw milk in Khartoum North (Sudan) and their susceptibility to antimicrobial agents. J. Animal Veterinary Advances, 4 (3): 341-344. 
التقييم البكتريولوجي للبن الخام والزبادي لوجود ستافيلوكوكاس اوريوس مع إثـارة خاصة للسموم المعوية

$$
\text { محمود فرغلي حسين ، ايمن منير إبراهيركريّيم }
$$

E-mail: Mahmoutfarghaly_1970@yahoo.com

Assiut University web-site: www.aun.edu.eg

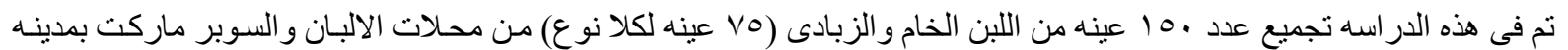

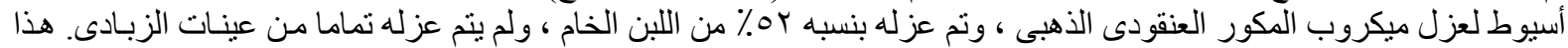

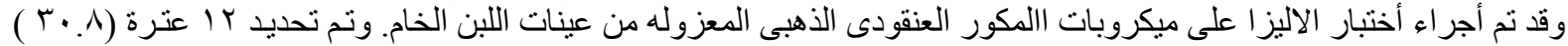

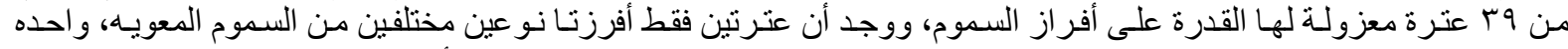

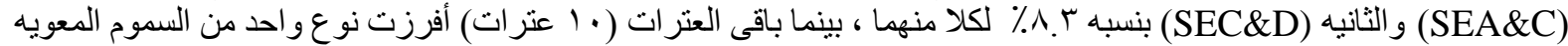

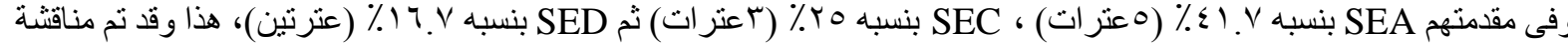

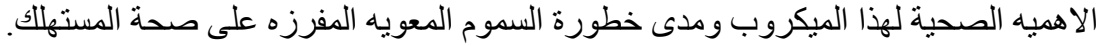

